Onder 306 viles is Nones

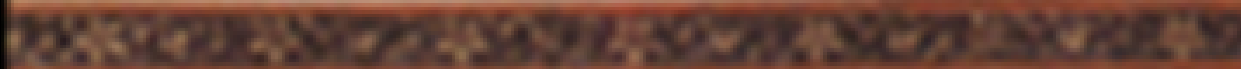

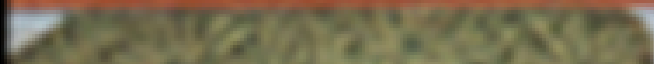

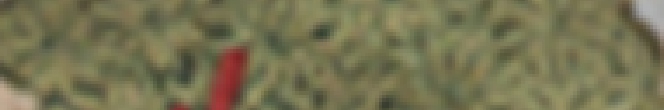
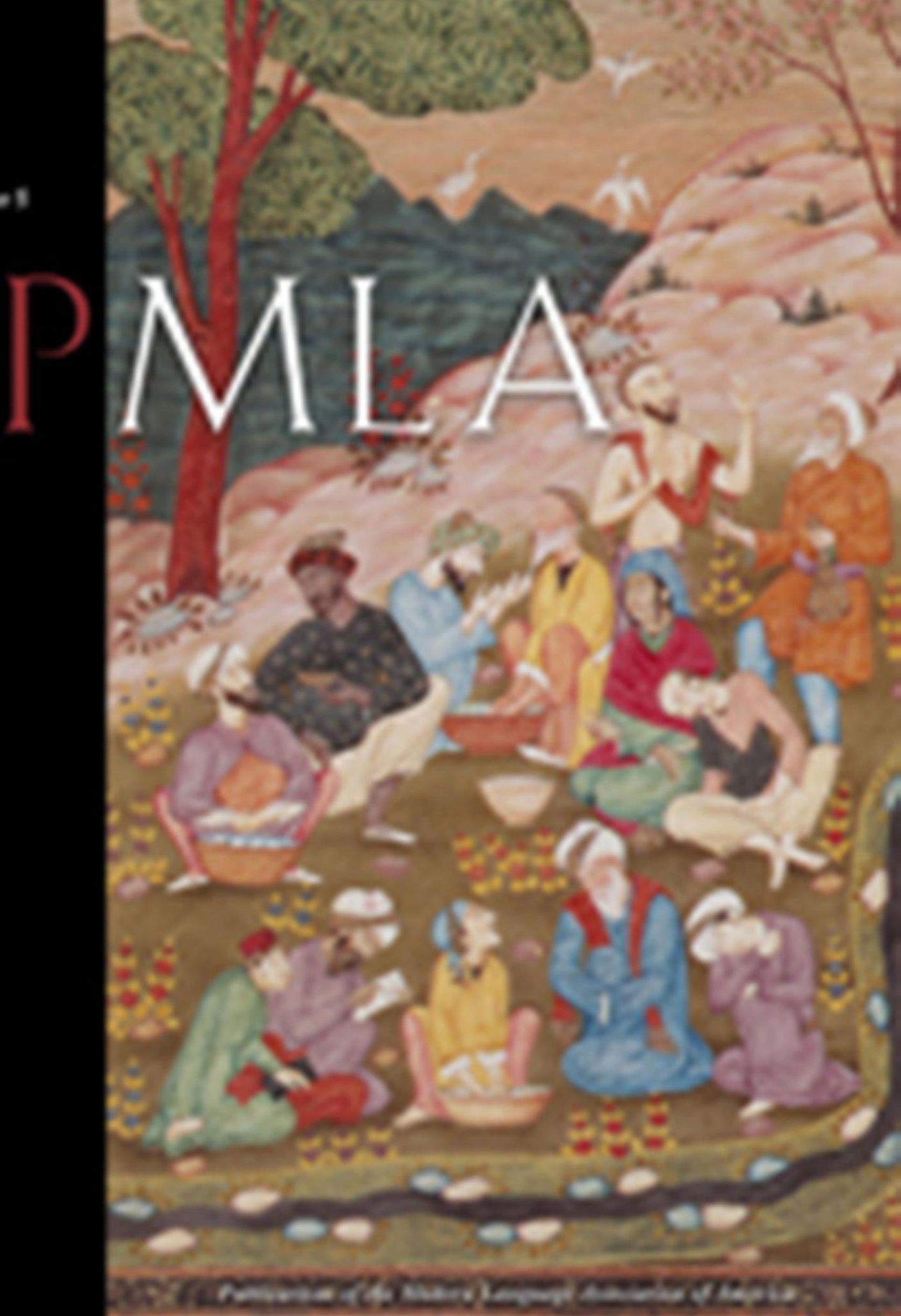


\section{October 2019}

Volume 134 Number 5

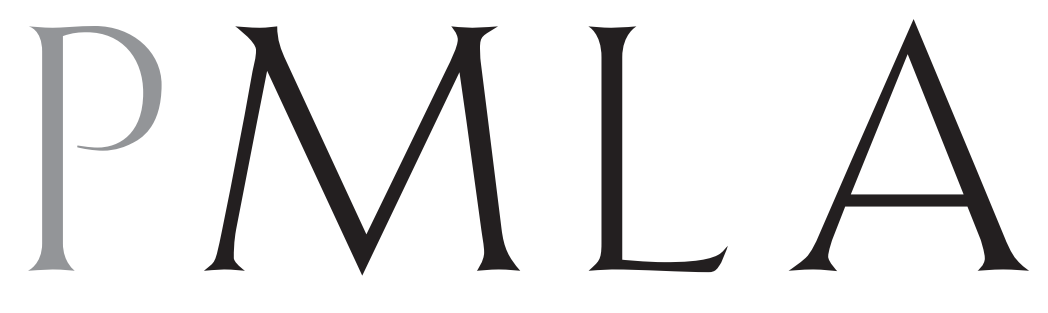

Publications of the Modern Language Association of America 
THE MODERN LANGUAGE ASSOCIATION OF AMERICA

Organized 1883, Incorporated 1900 Officers

FOR THE TERM ENDING 12 JANUARY 2020 President

Simon E. Gikandi

Princeton University

First Vice President

JUdith Butler

University of California, Berkeley

Second Vice President

BARBARA FUCHS

University of California, Los Angeles

Executive Director

Paula M. Krebs

Executive Council

FOR THE TERM ENDING 12 JANUARY 2020

ANGelika BAMMER Emory University

Amanda Licastro

Stevenson University

David Tse-Chien Pan

University of California, Irvine

Rafael A. Ramirez Mendoza Emory University

FOR THE TERM ENDING 10 JANUARY 2021 ERIC Hayot

Penn State University, University Park EviE SHOCKLEY

Rutgers University, New Brunswick

Dana A. Williams

Howard University

FOR THE TERM ENDING 9 JANUARY 2022

JEAn Elizabeth Howard Columbia University

Elizabeth Mathews Losh College of William and Mary

LEAH RICHARDS

LaGuardia Community College,

City University of New York

RAMON SALDIVAR

Stanford University

FOR THE TERM ENDING 8 JANUARY 2023

Ann Kalscheur Suarez MiraCosta College, CA

Anjali Prabhu

Wellesley College

Julie SHOUlTs

Muhlenberg College

Trustees of Invested Funds

Simon E. Gikandi

Eric Hayot

William H. JANEWAY

(Managing Trustee)

New York, New York

Domna C. Stanton

New York, New York

CATHARINE R. STIMPSON

New York, New York

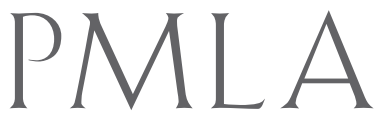

PUBLICATIONS OF

THE MODERN LANGUAGE ASSOCIATION OF AMERICA

[ Published five times a year $]$

Available online at JSTOR and MLAJournals.org;

indexed in the MLA International Bibliography.

Editor

WAI CHEe Dimock

Yale University
Director of

Scholarly Communication

Angela Gibson

Head of Periodical Publications

SARA PASTel

Senior Editor

BARNEY LATIMER
Associate Editors

JOHN D. GOLBACH

JOSEPH WALLACE

Senior Advertising Manager and

Submissions Associate

ANNABEl SCHNEIDER

Editorial Assistant

IsABEL XiaOYue GuAN
PMLA (ISSN 0030-8129) is published five times a year, in January, March, May, September, and October, by the Modern Language Association of America. Membership in the association is open to persons who are professionally interested in the modern languages and literatures. Information about annual dues, which include subscription to $P M L A$, is available at www.mla.org/Membership/About-Membership. Membership applications are available on request and at www.mla.org/Membership/Join-the-MLA.

For libraries and other institutions, a subscription in 2019 to the electronic format of $P M L A$ alone is $\$ 220$ and to the print and electronic formats is $\$ 240$ (domestic and Canadian) or $\$ 275$ (foreign). Subscriptions also include online access to the $2002-18$ volumes. Agents deduct four percent as their fee. Claims for undelivered issues will be honored if they are received within six months of the publication date; thereafter the single-issue price will be charged. To order an institutional subscription, call or write MLA Member and Administrative Services (646 576-5166; subscrip@mla.org).

Single copies of issues for the current year and the previous one are available at www .mla.org/store/CID70 and from MLA Member and Administrative Services (646 576-5161; bookorders@mla.org).

The MLA publication and editorial offices are located at 85 Broad Street, suite 500, New York, NY 10004-2434 (646 576-5000; pmlasubmissions@mla.org).

All communications concerning membership, including change-of-address notifications, should be sent to Member and Administrative Services, MLA, 85 Broad Street, suite 500, New York, NY 10004-2434 (646 576-5151; membership@mla.org).

Periodicals postage paid at New York, NY, and at additional mailing offices.

(c) 2019 by The Modern Language Association of America. All rights reserved. Printed in the United States of America. MLA and the MODERN LANGUAGE ASSOCIATION are trademarks owned by the Modern Language Association of America.

Library of Congress Catalog Card Number 12-32040. United States Postal Service Number 449-660.

POSTMASTER: Send address changes to PMLA, Member and Administrative Services, MLA, 85 Broad Street, suite 500, New York, NY 10004-2434. 


\section{Contents}

985 Submitting Manuscripts to PMLA

986 Forthcoming in PMLA

986 Features in PMLA

989 Editor's Column-Hanging with Chefs

996 Having a Coke with You Is Even More Fun Than Ideology Critique

Brian Glavey

1012 The Green and the Black: Ecological Awareness and the Darkness of Noir

LUCAS Hollister

1028 Thomas Hardy's Groundwork

DANIEL WRIGHT

1042 Antiessentialist Form: The Bebop Effect of Percival Everett's Erasure

JOHN BROOKS

1056 Proletarian Modernism: Film, Literature, Theory Benjamin Kohlmann

1076 The Innocent Old Way: Reserved Interpretation and Christina Rossetti's "Goblin Market”

Aubrey Plourde

\section{little-known documents}

1094 From the Gutter to the Gallery: Berenice Abbott Photographs Mina Loy's Assemblages

Berenice Аbbott and Mina Loy

Introduction by Amy E. Elkins

1104 Notes on the Trip to the Great Savannah

Alejo Carpentier

INTRODUCTION AND TRANSLATION BY CHARLOTTE ROGERS
Editorial Board

Faith E. Beasley, 2020

Dartmouth College

GALEN BROKAW, 2021

Montana State University, Bozeman

Christopher Cannon, 2020 Johns Hopkins University

Peter J. Kalliney, 2021 University of Kentucky

Susan Koshy, 2020

University of Illinois, Urbana

ILYA Vinitsky, 2021

Princeton University

\section{Advisory Committee}

Eric Gary ANDERSON, 2022

George Mason University

Bernadette Andrea, 2021

University of California, Santa Barbara

ANke BirkenMaier, 2020

Indiana University, Bloomington

C. D. Blanton, 2022

University of California, Berkeley

Tobias Boes, 2022

University of Notre Dame

KARL AshoKa BRITTO, 2021

University of California, Berkeley

A. Suresh Canagarajah, 2020

Penn State University, University Park

Katharine Capshaw, 2022 Princeton University

Michael C. Cohen, 2022 University of California, Los Angeles

BRADIN CORMACK, 2020 Princeton University

JefFrey N. CoX, 2021

University of Colorado, Boulder

Jenny Davidson, 2022 Columbia University

Martin G. EISNER, 2022 Duke University

Maud Ellmann, 2021

University of Chicago

JACQUELINE ANN FAY, 2021

University of Texas, Arlington

Amalia Gladhart, 2020 University of Oregon

Erin D. Graff Zivin, 2021 University of Southern California

Paola S. Hernandez, 2021

University of Wisconsin, Madison

HÉctor Hoyos, 2020 Stanford University

Catherine Elizabeth Ingrassia, 2021

Virginia Commonwealth University

CAREN IRR, 2020

Brandeis University

(continued) 
Advisory Committee (continued)

KaTHRYN LACHMAN, 2021 University of Massachusetts, Amherst Jesse MaCliesh Lander, 2021

University of Notre Dame

Leila Maria Lehnen, 2022 Brown University

Lital LeVy, 2021 Princeton University

Mary McAlpin, 2020 University of Tennessee, Knoxville

Jane Ogden Newman, 2022

University of California, Irvine

Mario ORTIZ-Robles, 2021

University of Wisconsin, Madison

Kate Paesani, 2020

University of Minnesota, Twin Cities

JoRge P. PÉREZ, 2020

University of Texas, Austin

Samantha Pinto, 2020

Georgetown University

JUAN G. RAMOS, 2021

College of the Holy Cross

Alan RaUCH, 2022

University of North Carolina, Charlotte

Elizabeth RHODES, 2020 Boston College

SARAH Robbins, 2020 Texas Christian University

Carlos Rojas, 2021 Duke University

IgNacio SANCHEZ PRADO, 2022 Washington University in St. Louis

Debarati Sanyal, 2020

University of California, Berkeley

JoNATHAN STONE, 2022

Franklin and Marshall College

Elisa TAMARKIN, 2022 University of California, Berkeley

Miriam Thaggert, 2021 University of Iowa

Alexandra K. Wettlaufer, 2021

University of Texas, Austin

STEFAN WHeELOCK, 2020

George Mason University

SARAH WiNTER, 2020

University of Connecticut, Storrs
OCTOBER 2019

theories and methodologies

Poetics of Fact, Politics of Fact

1109 Introduction to "Poetics of Fact, Politics of Fact"

Colleen Glenney Boggs and Chenxi Tang

1115 The Facts on the Ground

Peter Brooks

1121 The Facts of Law

Marianne Constable

1129 Facts, Fictions, Counterfactuals

Catherine Gallagher

1136 Alternate-Reality Effects

Paul K. Saint-Amour

1143 Facts, Faction, Anachronism

Russ Castronovo

1150 Facts Shifting to the Left: From Postmodernism to the Postfactual Age

Albrecht Koschorke

Translated by Michael Thomas Taylor and Sasha Rossman

1157 When Nothing Is True, Everything Is Possible: On Truth and Power by Way of Socialist Realism

Haiyan Lee

1165 Making Facts, Using Facts: Two Poetics of the Factual and One Theory of the Political

Chenxi Tang

1173 Minutes of the MLA Executive Council

1180 In Memoriam

1182 Index of Advertisers

1195 Abstracts 